\title{
CATEGORIZATION, FAST AND SLOW
}

\author{
Vasyl Starko \\ vasyl_starko@yahoo.com \\ Lesya Ukrainka Eastern European National University, Ukraine
}

Received May 23, 2017; Revised June 23, 2017; Accepted June 26, 2017

\begin{abstract}
The title of this study is inspired by Daniel Kahneman's best-selling book Thinking, Fast and Slow. In it, the Nobel Prize winner explains in great detail the working of two systems of human reasoning: System 1, which is fast, automatic, associative, subconscious, involuntary and (nearly) effortless, and System 2, which is slow, intentional, logical, conscious, effortful and requires executive control, attention, and concentration. It is our contention that this distinction applies to human categorization as well. We subscribe to the view that each of the two labels refers, in fact, to a set of systems and call them Type 1 and Type 2 processes. Analyzing and re-interpreting well-known examples found in linguistic literature and our own data, we argue that Type 1 categorization relies on the 'shallow' linguistic representation of the world, while Type 2 tends to use 'deep' extralinguistic knowledge. The differences between Type 1 and Type 2 categorization are also evident in psycholinguistic experiments and evaluations of linguistic data elicited from speakers. A conclusion is drawn about the need to take this distinction into account in psycholinguistic and linguistic research on categorization.
\end{abstract}

Keywords: categorization, category, dual-process theory, Type 1, Type 2, linguistic representation of the world.

Старко Василь. Категоризація, швидка й повільна.

Анотація. Назва цієї розвідки інспірована книжкою Деніела Канемана «Мислення, швидке й повільне», в якій автор, нобелівський лауреат, докладно пояснює роботу двох систем мислення людини: системи 1 - швидкої, автоматичної, асоціативної, підсвідомої, мимовільної системи, що (майже) не вимагає зусиль, і системи 2 - повільної, умисної, логічної, свідомої системи, що вимагає зусиль, контролю за виконанням, уваги й концентрації. автор обстоює тезу, що ця відмінність стосується також сфери людської категоризації й приймаємо положення про те, що кожна з цих назв позначає, насправді, набір систем, що їх ми позначаємо «процеси типу 1» і «процеси типу 2». Аналізуючи та реінтерпретуючи відомі приклади 3 лінгвістичної літератури та власні дані, обгрунтовано, що категоризація типу 1 спирається на 'неглибоку' мовну картину світу, а категоризація типу 2 залучає 'глибокі' позамовні знання. Відмінність між категоризацією типу 1 і типу 2 виявляється й у психолінгвістичних експериментах та оцінках мовних даних, отриманих від носіїв мови. Зроблено висновок про потребу враховувати цю відмінність у психолінгвістичних і лінгвістичних дослідженнях категоризації.

Ключові слова: категоризація, категорія, теорія подвійних процесів, тип 1, тип 2, мовна картина світу.

\section{Introduction}

Daniel Kahneman's best-selling book Thinking, Fast and Slow (Kahneman, 2015) and other literature point to the existence of two systems of information processing in human cognition. We believe that valuable insights into human categorization can be gained by adopting this dual processing perspective. Our goal is to bridge the gap between dual-process research in psychology and linguistic research and show how the dual-processing approach can be applied in the study of categorization. 
It appears that there two kinds of processes involved: ample psycholinguistic data reflect the neural organization of the brain and spreading activation effects, which are the manifestation of the fast, implicit, unconscious categorization process. In contrast, the working of the explicit and conscious process is evident in situations when the categorizing subject has to make an effort, exercise control, and in general proceed with deliberation, relying on the slow categorization system. It should be noted that these systems may overlap with but are not necessarily identical with categorization models, such as the classical model, family resemblance model, prototype theory, exemplar theory, etc.

Theories of dual processing go back to the 1970s and 1980s (Wason \& Evans, 1975) and have become extremely common in psychology in a variety of areas, such as emotion (Teasdale, 1999), psychology of learning (Reber, 1993; Sun, Slusarz, \& Terry, 2005), judgment and decision making (Kahneman \& Frederick, 2002; Kahneman, 2015), and social cognition (Chaiken \& Trope, 1999), in particular person perception ( , Sanders, \& Garza, 2000), stereotyping (Devine, 1989), etc.

A variety of labels have been used in psychology in this context: System 1 and System 2, which gained popularity following (Stanovich, 1999); dual systems; fast and slow system; implicit and explicit system; intuition and reasoning (Kahneman, 2003); heuristic and systematic processing, etc. However, it has been argued that many of these designations are misleading because they may suggest the (incorrect) idea that there are exactly two systems at work. To emphasize such plurality, in this study they will be called Type 1 and Type 2 processes in the following sense: "These terms indicate qualitatively distinct forms of processing but allow that multiple cognitive or neural systems may underlie them" (Evans \& Stanovich, 2013:226). Both Type 1 and Type 2 refers to a set of systems in the brain. Types of mental processing should not be confused with modes of processing, which are cognitive styles subsumed under Type 2 processes.

There are a number of properties typically associated with the two types of processing (summarized in Table 1). Note that these attributes might not all co-occur in a given dual-processing situation.

Table 1

Some attributes associated with Type 1 and Type 2 processes, based on (Evans \& Stanovich, 2013), (Kahneman, 2015)

\begin{tabular}{|l|l|}
\hline Type 1 processes & Type 2 processes \\
\hline Fast & Slow \\
\hline Automatic & Controlled \\
\hline Unconscious & Conscious \\
\hline Implicit & Explicit \\
\hline Associative & Rule-based \\
\hline Low effort & High effort \\
\hline High capacity & Limited capacity \\
\hline Contextualized & Abstract \\
\hline Independent of working memory & Limited by working memory capacity \\
\hline Parallel & Serial \\
\hline Non-logical & Logical \\
\hline
\end{tabular}


The default-interventionist architecture of Type 1 and Type 2 processes, accepted here, presupposes the following: Type 1 processes constantly and automatically generate default responses (activate respective categories in the brain), while Type 2 processes may or may not be called to intervene and correct or modify these (Kahneman \& Frederick, 2002; Kahneman, 2015). There is growing neuroscientific evidence to support this kind of architecture showing that, unlike Type 1, Type 2 processing requires the activation of brain regions associated with executive control (Evans \& Stanovich, 2013).

It has been observed on many occasions (see, for example, (Lakoff, 1987)) that, under normal circumstances in everyday activities, categorization occurs largely unconsciously. Type 1 categorization processing proceeds roughly in the following manner: our attention is involuntarily captured by the sensory properties of objects, which leads to the automatic activation of certain knowledge structures. This may or may not be coupled with (unproblematic) verbalization. The object of categorization and the situation in which it is categorized provide multiple converging clues with regard to the relevant category, and the Type 1 categorization proceeds unimpeded. In fact, whenever we conveniently and effortlessly rely on the linguistically motivated representation of the world (linguistic world view, linguistic picture of the world) and let it guide us in our thinking and action, we use Type 1 categorization. However, in cases when categorization is challenging, uncertain, or problematic in some way, this reliance fails and Type 2 processes are called to intervene. The reasons and situations in which this occurs are diverse, but in every case the categorizing subject is forced to deliberate and consciously manipulate mental representations for the purpose of successful categorization (Barrett, Tugade \& Engle 2004:554). This requires control, attention, the engagement of working memory, etc. Most important, Type 2 categorization triggers certain operations over the representations of a given category that may differ from those involved in Type 1 categorization processes.

\section{Methods}

In order to show that the dual-processing theory is relevant for categorization research, we re-interpret well-known examples published in linguistic literature and analyze our own linguistic data obtained by way of observation in the light of this theory. Additionally, we identify the types of linguistic data that correspond to Type 1 and Type 2 categorization processing. Moreover, for the purpose of illustrating the benefits of the dual-processing approach in resolving some long-stand ing paradoxes and contradictions in research on categorization, we offer a dual-processing interpretation of the results of psycholinguistic experiments and speakers' evaluations of linguistic data that have been reported in oft-cited publications and perceived as being mutually contradictory.

\section{Results and Discussion}

Let us consider a famous example provided by Benjamin Lee Whorf (1956). People tend to be careless with smoking and cigarettes around gasoline drums that 
are 'empty', whereas they, in fact, contain explosive vapor and are highly dangerous. The entire situation as categorized via Type 1 processing leads to the superficial conclusion that there is nothing left in these containers and, hence, they are not hazardous. It requires conscious reasoning and the involvement of Type 2 processing for the subject to become aware of the presence of vapor and the danger it poses. Type 2 processes may be engaged by the categorizing subject himself/herself (due to his/her inherent vigilance and alertness) or in response to an admonition from a better informed person. Noteworthily, Type 1 categorization is 'shallow' in that it involves merely the linguistic meaning of empty 'containing nothing', whereas deliberate categorization involves non-linguistic knowledge of the world (gasoline drums contain vapor). This extralinguistic knowledge ultimately comes into conflict with linguistically guided, effortless, fast categorization.

Another example when Type 2 categorization processing intervenes is when a person studies a foreign language. From our experience, an English-speaking student of Ukrainian will find it relatively easy to learn the Ukrainian color words for, say, red and green but will be much more challenged by the Ukrainian synii, blakytnyi, and holubyi, which together cover the denotational range of the English blue. The student will need to engage Type 2 processing repeatedly and persistently to properly name lighter and darker shades of blue in Ukrainian. Conversely, a Ukrainian student of English will have to resort to Type 2 processes in order to learn to correctly designate, for example, arm and hand and foot and leg in English, because Ukrainian typically uses just one word in each case-ruka and noha. Thus, conscious effort and attention are required-at least initially, before entrenchment and routinization occur-because of conflicting L1 and L2 categorization patterns.

Now consider the following interaction occurring late at night:

Speaker 1: I'm tired. Let's return to this task tomorrow.

Speaker 2: OK. But it's already past midnight, so we'll get back to it today, not tomorrow.

Dialogues along these lines have been witnessed by the author multiple times (between speakers of Ukrainian). The use of tomorrow and today is dictated by the invocation of two different frames of reference. Speaker 1 automatically uses the naive understanding that two successive days are separated by the night (night sleep), whereas Speaker 2 (probably after checking the time) refers to a more rigorous clock-based model. This involves conscious effort and, thus, Type 2 processing. This example is an illustration of the type of situations in which reference is made not to the linguistic model of the world but to a different reference frame.

One common subtype is a conflict with the scientific model of the world. There are many examples of divergences, big and small, between the linguistic and scientific models. To give just one example, the naïve and scientific understand ing of nuts and fruit differ along the following lines: "Technically, any seed-containing part of a plant is the fruit of that plant; as such, nuts in general are fruit. In ordinary language, on the other hand, nuts and fruit are basically distinct categories (regardless of the possible boundary status of the coconut): nuts are dry and hard, 
while fruits are soft, sweet, and juicy; also, the situations in which nuts and fruits are eaten are typically different." (Geeraerts, 1993: 239).

Stereotypes embodied in linguistic structures are another result of Type 1 categorization processing. In stereotyping, certain features are ascribed to a category and are automatically associated with any particular representative of this category (until experience or other factors prove the association wrong). An extensive body of literature in social psychology (Chaiken \& Trope, 1999) and other disciplines is focused on stereotyping. Stereotypes may or may not be true to reality, but the defining characteristic is that they are available in the Type 1 shallow processing, i.e., automatically activated, and serve to simplify information and make sense of the world. Once stereotypes are formed, they are persistent and extremely difficult to overcome. It takes serious experiences or other weighty impact to help a person learn to overcome entrenched stereotypes, and even then, they do not disappear but are, rather, put under control.

Another class of cases when Type 1 categorization fails includes situations when an object is hard (or impossible) to categorize easily. For example, an object of an unusual shape and unclear function may present difficulties. Novel objects that have never been seen before are hard to categorize as well. There are also borderline cases when an object combines the features of two or more categories. Consider the following exchange:

- Daddy, are skis a vehicle?

- Well, in a way they are. (Which means that they possess some features of a vehicle or may serve the same purpose as a vehicle, but they are also different from the members of the vehicle category in important ways.)

In such cases, speakers often employ hedges (Lakoff, 1973). We have singled out a large group of categorization-related hedges which are present in various languages and which we call categorization qualifiers, such as loosely speaking, in broad terms, by and large, up to a point, in a narrow (strict) sense, in a way, in a manner of speaking, in name only, technically, etc (Starko, 2013).

One of the manifestations of Type 2 categorization is newly coined words or, more generally, innovative nominalization. We identify this class of lexemes as Type 2 categorization products on the following basis: the categorizing subject feels the inadequacy of established terms for the designation of an object or phenomenon at hand; thus, the speaker come up with a new designation by using available linguistic units and adding qualifying formants to them. From our observations, such nominations frequently refer to objects that do not meet the qualitative requirements for category members or do not quite fit the category, e.g., quasi-patriots, semiknowledge, German Ersatzkaffee, Ukrainian nedomystetstvo (literally, not-quite-art), and so on.

Now let us consider an apparent contradiction between the results of some psycholinguistic experiments and speakers' deliberate evaluation of linguistic data and see how it can be explained from the position of the dual-processing account of human categorization. In her seminal paper (1973: 133), Eleanor Rosch Heider reported the results of psycholinguistic experiments which revealed that category 
members form a scale of exemplariness from the 'best' category members to the 'worst':

fruit: apple, plum, pineapple, strawberry, fig, olive;

vehic le: car, boat, scooter, tricycle, horse, skis;

bird: robin, eagle, wren, chicken, ostrich, bat;

vegetable: carrot, asparagus, celery, onion, parsley, pickle;

disease: cancer, measles, cold, malaria, muscular dystrophy, rheumatism.

These results were produced by respondents who had been asked to rate category members on a scale. Moreover, in a sentence verification test, response times for more central members were faster than for more peripheral members. George Lakoff (1973: 460) inferred from these findings that category membership is a matter of degree: "Degree of truth (corresponding to degree of category membership)

a. A robin is a bird. (true)

b. A chicken is a bird. (less true than a)

c. A penguin is a bird. (less true than $b$ )

d. A bat is a bird. (false, or at least very far from true)

e. A cow is a bird (absolutely false)"

Being an honest researcher, he then reported: "Most speakers I have checked with bear out this judgment, though some seem to collapse the cases [a-c], and don't distinguish among them." This sentiment was then echoed and amplified by Anna Wierzbicka (1996:151): "It is hard to see, however, how this reasoning [about degrees of category membership] can be reconciled with native speakers' firm intuition that whereas a bat is definitely not a bird at all, an ostrich is a bird-a "funny" bird, an atypical bird, but a bird." Wierzbicka argues for features that are necessary (rather than prototypical) components of the concept 'bird' but are not necessarily realized in all members of the category 'bird': "properties such as flying, feathers, and so on are presented as essential parts of the prototype, not as necessary features of every bird" (Wiezbicka 1996:164). Thus, there are birds that cannot fly, but they are still categorized as birds. The same argument applies to many other concepts: raspberries are fruit, but unlike prototypical fruit, they do not grow on trees; tomatoes are thought of as being red, even though there are yellow tomatoes; cabbage is greenish, but there is also the so-called red cabbage; prototypical apples are construed as being red, despite the existence of green and yellow apples, and so on (Wierzbicka, 1996:164-165).

It should be noted that psycholinguistic findings that point to graded prototypicality are just as real as the intuition that there is (at least for some cases) a clear, cut-and-dried category boundary separating birds from non-birds.

The apparent contradiction between the results obtained by Rosch and what was reported by Lakoff's respondents and elicited by Wierzbicka via her own linguistic intuition and observation lies in the distinction between Type 1 and Type 2 categorization processing. These results are, in fact, complementary rather than contradictory. There are many psycholinguistic experiments in which subjects are instructed to produce fast reactions, asked to quickly rank objects, or put under a 
time limit or in other conditions forcing them to rely solely on the speed of neural firing in association links. This is conducive to fast, automatic categorization, and such experiments yield the results of Type 1 categorization processing. These are valid results, but they uncover only part of the whole picture. In the case of deliberate categorization (evaluations by Lakoff's respondents and Wierzbicka's data), speakers appear to perform a weighting of features and draw a line between members and non-members. In doing so, they may, and sometimes do, reach further along their information network bringing extralinguistic knowledge to bear on their categorization judgments. This procedure does not rule out the presence of borderline and doubtful cases, but the structure of the category, as processed with the involvement of Type 2 categorization resources, is starkly different from the goodness-of-membership continuum typically yielded by Type 1 processes.

Clearly, this issue requires further investigation and analysis, but it is undeniable that psycholinguistic and linguistic research into categorization needs to take into account Type 1 / Type 2 differences.

\section{Conclusions}

The dual-process paradigm, common in psychology, applies to the domain of categorization. The distinctions between Type 1 and Type 2 categorization are revealed in various classes of cases. Type 1 processing is characteristic of linguistically guided representation of the world. Under normal circumstances, people uncritically follow this representation, relying on default mental representations activated via Type 1 processing. In a number of cases (for example, categorization of novel objects, conflicting results from a different frame of reference or L2 language pattern, etc.), Type 2 categorization processes intervene. These processes involve a re-evaluation of the mental constructs used by Type 1 processes and may involve extensive, 'deep' extralinguistic knowledge (as opposed to 'shallow' linguistic knowledge available to Type 1). Psycholinguistic research will benefit from taking into account the distinctions between these two types of categorization processes.

\section{References}

1. Barrett, F., Tugade, M. M., \& Engle, R. (2004). Individual differences in working memory capacity in dual-process theories of the mind. Psychological Bulletin, 130(4), 553-573.

2. Chaiken, S., \& Trope, Y. (Eds.). (1999). Dual-process theories in social psychology. New York, NY: Guilford Press.

3. Devine, P. G. (1989). Stereotypes and prejudice: Their automatic and controlled components. Journal of Personality and Social Psychology, 56, 5-18.

4. Evans, J. St. B. T., \& Stanovich, K. (2013) Dual-process theories of higher cognition: Advancing the debate. Perspectives on Psychological Science, 8(3), 223-241.

5. Geeraerts, D. (1993). Vagueness's puzzles, polysemy's vagaries. Cognitive Linguistics, 4(3), 223-272.

6. Heider, Eleanor Rosch (1973). On the internal structure of perceptual and semantic categories. In: Cognitive Development and the Acquisition of Language, (pp. 111-144). T. E. Moore, (ed.). New York: Academic Press 
7. Kahneman, D. (2003). A perspective on judgement and choice. American Psychologist, 58, $697-720$.

8. Kahneman, D. (2015). Thinking, Fast and Slow. New York: Farrar, Straus and Giroux.

9. Kahneman, D., \& Frederick, S. (2002). Representativeness revisited: Attribute substitution in intuitive judgement. In: Heuristics and Biases: The Psychology of Intuitive Judgment, (pp. 49-81). T. Gilovich, D. Griffin, \& D. Kahneman, (eds.). Cambridge, MA: Cambridge University Press.

10. Lakoff, G. (1973). Hedges: A study in meaning criteria and the logic of fuzzy concepts. Journal of Philosophical Logic, 2, 458-508.

11. Lakoff, G. (1987). Women, Fire, and Dangerous Things. Chicago, London: University of Chicago Press.

12. Reber, A. S. (1993). Implicit Learning and Tacit Knowledge. Oxford, England: Oxford University Press.

13. Stanovich, K. E. (1999). Who is Rational? Studies of Individual Differences in Reasoning. Mahwah, NJ: Erlbaum.

14. Stanovich, K. E., \& West, R F. (2000). Individual difference in reasoning: implications for the rationality debate? Behavioural and Brain Sciences, 23, 645-726.

15. Старко В. Категоризаційні кваліфікатори// Проблеми зіставної семантики. 2013, № 11. С. 132-138.

Starko, V. (2013). Katehoryzatsiini kvalifikatory. Problemy Zistavnoyi Semantyky, 11, 132-138.

16. Sun, R., Slusarz, P., \& Terry, C. (2005). The interaction of the explicit and the implicit in skill learning: A dual-process approach. Psychological Review, 112, 159-192.

17. Teasdale, J. D. (1999). Multi-level theories of cognition-emotion relations. In: Handbook of Cognition and Emotion, (pp. 665-681). T. Dalgleish \& M. J. Power, (eds.). Chichester, England: Wiley.

18. Wason, P. C., \& Evans, J. St. B. T. (1975). Dual processes in reasoning? Cognition, 3, $141-154$.

19. Whorf, B. L. (1956). The relation of habitual thought and behavior to language. In: Language, Thought, and Reality. Selected Writings of Benjamin Lee Whorf, (pp. 134159). Cambrid ge, Massachusetts: The M.I.T. Press. (originally published in 1941)

20. Wierzbicka, A. (1996). Semantic Primes and Universals. Oxford: Oxford University Press.

21. rate, M. A., Sanders, J. D., \& Garza, A. A. (2000). Neurological disassociations of social perception processes. Social Cognition, 18, 223-251. 